\title{
Recent Advances in Basic Research for Brain Arteriovenous Malformation
}

\author{
Leandro Barbosa Do Prado ${ }^{1,+(1)}$, Chul Han ${ }^{2, \dagger}$, S. Paul Oh ${ }^{2, \mp(}$ and Hua Su ${ }^{1, *, \neq(1)}$ \\ 1 Center for Cerebrovascular Research, Department of Anesthesia, University of California, San Francisco, \\ CA 94143, USA; Leandro.BarbosaDoPrado@ucsf.edu \\ 2 Barrow Aneurysm \& AVM Research Center, Barrow Neurological Institute/Dignity Health, Phoenix, \\ AZ 85013, USA; Chul.Han@dignityhealth.org (C.H.); ohp@barrowneuro.org (S.P.O.) \\ * Correspondence: hua.su@ucsf.edu; Tel.: +01-415-206-3162 \\ + These authors contributed equally to this work. \\ $\ddagger$ Co-senior authors.
}

Received: 3 August 2019; Accepted: 21 October 2019; Published: 25 October 2019

\begin{abstract}
Arteriovenous malformations (AVMs) are abnormal connections of vessels that shunt blood directly from arteries into veins. Rupture of brain AVMs (bAVMs) can cause life-threatening intracranial bleeding. Even though the majority of bAVM cases are sporadic without a family history, some cases are familial. Most of the familial cases of bAVMs are associated with a genetic disorder called hereditary hemorrhagic telangiectasia (HHT). The mechanism of bAVM formation is not fully understood. The most important advances in bAVM basic science research is the identification of somatic mutations of genes in RAS-MAPK pathways. However, the mechanisms by which mutations of these genes lead to AVM formation are largely unknown. In this review, we summarized the latest advance in bAVM studies and discussed some pathways that play important roles in bAVM pathogenesis. We also discussed the therapeutic implications of these pathways.
\end{abstract}

Keywords: brain arteriovenous malformation; somatic mutation; RAS-mitogen-activated protein kinases (MAPK); hereditary hemorrhagic telangiectasia; TGF $\beta$; PDGF-B/PDGFR-B

\section{Introduction}

Brain arteriovenous malformations (AVMs) are abnormal vessels that are prone to rupture, causing life-threatening intracranial hemorrhage (ICH) [1]. The estimated prevalence of brain AVMs (bAVMs) is $0.05 \%$ (95\% CI: $0.01 \%$ to $0.10 \%$ ) among otherwise healthy individuals [2]. Patients with bAVMs may remain asymptomatic or experience epileptic seizures, focal neurological deficits, or ICH, which is the most feared complication and the primary reason to treat. Overall, bAVMs account for $25 \%$ of hemorrhagic strokes in adults younger than 50 years of age [3], and up to $40 \%$ of bAVM patients die or remain functionally impaired within one year after ICH [4]. Each of the existing treatment modalities carries a non-trivial rate of procedure-related complications, although the mortality varies among hospitals [5-7]. With the advance of imaging techniques, more asymptomatic bAVM patients will be diagnosed. The treatment of asymptomatic patients has become increasingly controversial because findings from a randomized trial of unruptured bAVM (ARUBA) showed that stroke and mortality were lower in unruptured $\mathrm{bAVM}$ patients randomized to conservative management than patients who received any interventional therapy [5,6,8-11]. Currently, there is no specific medical treatment available. Uncovering bAVM pathogenesis is essential for the development of specific therapies to minimize the need for invasive procedures.

More than $95 \%$ of bAVMs are sporadic cases without a clear family history. The causative gene for sporadic bAVM is largely unknown. Recent studies identified somatic mutations of genes in the 
RAS-MAPK pathways in sporadic bAVMs and extra-neural AVMs [12,13]. The significance of these genes in AVM formation needs to be studied further.

The familial forms of the more common sporadic disorders have been used to study the disease mechanisms of sporadic cerebrovascular diseases [14-22]. The most studied familial form of bAVM cases is associated with a genetic disorder called hereditary hemorrhagic telangiectasia (HHT). More than $90 \%$ of HHT patients have mutations in transforming growth factor $\beta$ (TGF $\beta$ ) family receptors, endoglin (ENG), or activin receptor-like kinase 1 (ALK1 or $A C V L R 1)$.

Although many pathways and modifier genes are implicated in bAVM pathogenesis, in this review, we focused on recent discoveries in RAS-MAPK-ERK, TGF $\beta$, platelet-derived growth factor $b$ (Pdgfb) pathways, and non-cording RNAs in bAVM studies.

\section{RAS-MAPK-ERK Signaling in Sporadic bAVM}

The RAS pathway includes different signaling cascades, such as RAF-MEK-MAPK/ERK. This pathway regulates several critical cellular functions, including proliferation, growth, survival, and senescence [23]. It has been documented that alteration of the RAS-MAPK pathway triggers tumorigenesis in humans as a result of abnormal activation of receptor tyrosine kinases mutations [24]. Subsequent studies showed KRAS mutations are present in colorectal, lung, and biliary tract carcinogenesis, while mutations in NRAS and HRAS are frequently present in a high percentage in melanomas and salivary gland tumors, respectively [25]. Of note, $90 \%$ of pancreatic adenocarcinomas harbor a RAS mutation [26]. Furthermore, it has been shown that ERK5 regulates several signaling pathways involved in angiogenesis, whereby it can inhibit the expression of VEGF during hypoxic response [27].

Recent studies have identified somatic mutations in genes in the RAS-MAPK pathway in sporadic bAVMs and extra-neural AVMs [12,13], through next-generation sequencing of DNAs isolated from patients' AVM lesions. The authors found somatic activating KRAS mutations in bAVM lesions from 45 of the 72 patients and in none of the 21 paired blood samples. The mutations included KRAS p.Gly12Val and the KRAS p.Gly12Asp mutations. Further investigation of the downstream signaling pathways, they found MAPK-ERK and PI3K-AKT pathways are activated by KRAS-activating mutations, in endothelial cell-enriched cultures derived from human bAVMs. The levels of ERK1/2 phosphorylation were increased in endothelial cells derived from bAVMs compared to the endothelial cells derived from normal brain vessels. AKT phosphorylation was not increased in bAVM endothelial cells. They showed that the mutations increased the expression of genes related to angiogenesis and Notch signaling. Introducing KRAS p.Gly12Val to cultured endothelial cells enhanced their migratory behavior. Interestingly, inhibition of MAPK-ERK but not PI3K pathway reversed the VEGF gene signature in endothelial cells [12]. A subsequent study showed that the prevalence of $K R A S / B R A F$ mutation was $81 \%$ in bAVMs and $100 \%$ in spinal AVMs [28]. These data indicate that somatic mutations in KRAS may contribute to the pathogenesis of human bAVMs.

Somatic mutations in genes involved in the RAS/MAPK pathway have also been detected in peripheral vascular malformations. Mosaic variants in genes in the RAS/MAPK pathway, including KRAS, NRAS, BRAF, and MAP2K1, have been detected in the lesions of intracranial and extracranial sporadic vascular malformations in children [29]. The mutations are more frequent in high-flow (AVM) than in low-flow (cerebral cavernous malformation) lesions. Introduction of these mutations to zebrafish resulted in vascular malformations that recapitulate human phenotypes. Treatment with a BRAF inhibitor, Vemurafenib, restored blood flow in malformed vessels in zebrafish. Couto et al. detected somatic MAP2K1 mutations in $64 \%$ of extracranial AVMs [13]. The mutation alleles were enriched in endothelial cells.

\section{TGF- $\beta$ Signaling in Familiar bAVM}

About $5 \%$ of bAVMs are linked to a genetic disorder, HHT, which is an autosomal dominant vascular disease that affects approximately 1 in 5000 people worldwide [30-32]. The major clinical 
feature of HHT is hemorrhage from AVMs in multiple organs, including the brain [33]. Three genes have been identified to cause HHT: ENG [34], ALK1 or ACVRL1 [35], and SMAD4 [36]. HHT is classified into HHT1, HHT2, and JP (juvenile polyposis)-HHT, depending on the causative gene mutations. HHT1 (ENG mutations) and HHT2 (ALK1 mutations) cover over $90 \%$ of all HHT cases [37]. Although clinical presentations are indistinguishable between HHT1 and HHT2, genotype-phenotype correlation studies have shown that HHT1 has a higher prevalence of AVMs in the brain and lungs, while HHT2 has a higher prevalence of AVMs in the liver and gastrointestinal tract [31,38-41]. Brain AVMs are present in $10.4 \%$ of patients with HHT. HHT1 patients have a significantly higher bAVM prevalence (13.4\%) compared with HHT2 patients (2.4\%) [42]. Most of the HHT-associated bAVMs are small (less than $3 \mathrm{~cm}$ ) and have a Spetzler-Martin grade of 2 or less; whereas, in the sporadic bAVM population, the mean bAVM nidus size is about $3 \mathrm{~cm}$, and the median Spetzler-Martin score is 3. While about $20 \%$ of these HHT-associated bAVMs present with rupture, nearly $50 \%$ of bAVMs are asymptomatic [42].

All identified genes associated with HHT are components of signal transduction of TGF- $\beta$ family members [43]; thus, HHT has been considered a disease caused by defects in the signaling of TGF- $\beta$ family member(s). However, detailed knowledge about the identity of the ligand(s), type II receptor(s), and downstream effectors genes of ENG-ALK1 signaling pertinent to AVM development are mostly unclear. Recent studies have shown that blockages for both BMP9 and BMP10 could induce AVM development in the retinal vasculature [44,45], but it is not entirely clear whether both BMP9 and BMP10 are needed for ENG-ALK1 signaling [46,47].

In addition to the canonical SMAD pathway, TGF $\beta$ family ligands also signal through non-SMAD signaling pathways [48]. ALK1-mutation increased pERK in cells treated with VEGF [49,50]. The phosphatase and tensin homolog (PTEN) connected BMP-9 activation of ALK1 to PI3K signaling in ECs [49,51]. BMP inhibits PI3K-AKT activity via the regulation of PTEN [50,52,53]. However, the absence of arteriovenous (AV) shunts in Pten-deficient mouse retina suggests that an increase of PI3K signaling by itself is not sufficient to trigger AVMs. One could speculate that increased PI3K signaling leads to AVMs only in the context of mutation in an AVM causal gene. Inhibition of MAPK-ERK by a MEK inhibitor suppressed ERK phosphorylation and restored localization of vascular ECs cadherin to the junctions of ECs carrying KRAS ${ }^{\mathrm{G} 12 \mathrm{~V}}$ mutation detected in brain AVM somatic cells. Inhibition of the MAPK-ERK also abrogated the VEGF-like gene signature induced by KRAS ${ }^{\mathrm{G} 12 \mathrm{~V}}$, but inhibition of the PI3K did not, suggesting that the phenotype of KRAS mutant ECs is specifically mediated by the MAPK-ERK [12]. These findings warrant further investigation to determine the extent to which these signaling pathways are involved in the development and progression of HHT-associated bAVMs.

Genetic mouse models of bAVM have been mostly developed by manipulating Eng or Alk1 genes. $E n g^{+/-}$or $A l k 1^{+/-}$heterozygous knockout $(\mathrm{KO})$ mice are viable and show HHT phenotypes during adulthood, while $\mathrm{Eng}^{-/-}$or Alk1 $1^{-/-}$homozygous KO mice are embryonic lethal [38,54-59]. bAVMs, including AV shunts and niduses of dilated vessels, occurred in only $30 \%$ of $E n g^{+/-}$mice aged 25 to 40 weeks with incomplete penetrance [56]. Brain AVMs did not develop effectively in mice with haploinsufficiency. The hypothesis that a somatic loss of heterozygosity increases AVM formation has been suggested based on animal studies. The deletion of both alleles in either the Alk1 or Eng gene was needed to develop bAVMs [60,61]. Alk1 deletion derived by the Alk1 gene promoter resulted in late gestational or postnatal lethality with AVMs in the brain, lung, and intestine, while tamoxifen-induced Alk1 deletion using R26-CreERT2 in adult mice resulted in AVMs and hemorrhage in visceral organs but not in the brain [62]. Since subdermal vasculatures of ALK1-deficient adult mice developed AVMs only in the presence of wounding [62], it was speculated that a secondary angiogenic or inflammatory stimulus would be required for AVM formation in adult brain.

Local VEGF delivery to the brain of Eng or Alk1-deficient adult mice led to vascular dysplasia, including AV shunting, enlarged tortuous vessels, and micro-hemorrhage [60,63-66], supporting a critical role of angiogenic stimulus as a secondary insult for de novo bAVM formation in Eng or Alk1-deficient adult mice. Gross vascular irregularities, including AV shunting and disrupted artery/vein-specific gene expressions, were seen in bAVM lesions in the Alk1-model [63]. 
Alk1 or Eng deficiency in vascular endothelial cells, but not smooth muscle cells, resulted in wound-induced skin AVMs in adult mice [67], while deletion of Alk1 in ECs, but not in pericytes and macrophages, along with a focal delivery of VEGF led to de novo bAVM formation in adult mice [60,65]. Together, these studies demonstrate that endothelial cells are the primary cells in which ENG-ALK1 signaling regulates for the proper formation of AV networks. Contrary to these studies, Alk1 or Eng deletion using smooth muscle-specific-SM22 $\alpha$-Cre led to the development of bAVMs, including tortuous vessels and hemorrhages in mice $[60,61]$. Although further investigations are needed to clarify, it is likely that a subset of ECs expressing Cre in this SM22 $\alpha$-Cre line [61] contributes to bAVM development in this model. An interesting study showed that transplantation of ENG-deficient bone marrow (BM) cells caused cerebrovascular dysplasia in wild-type mice after VEGF stimulation [68], suggesting a potential contribution of BM-derived EC progenitors in the pathogenesis of bAVM.

Brain AVMs lesions show high levels of inflammatory signals, including MMP-9 [69] and IL-6 [70]. An abnormally high number of macrophages were present in and around vascular walls in human bAVM specimens, with or without hemorrhage, suggesting that macrophage accumulation is not simply a response to hemorrhage $[69,71,72]$. Persistent macrophage infiltration and pro-inflammatory differentiation of monocytes in angiogenic tissues contributed to macrophage accumulation in bAVM. In Alk1- or Eng-deleted bAVM mouse models, the accumulation of macrophages in the brain angiogenic region started between 2 and 4 weeks after angiogenic stimulation before the bAVM formed and incrementally increased up to 8 weeks compared with wild-type mice. More CD34 ${ }^{+}$cells isolated from peripheral blood of HHT patients with either ENG or ALK1 gene mutation differentiated into macrophages than those from healthy controls [73]. However, the deletion of Eng in macrophages did not cause AVM formation [60], suggesting that gene deficiency in macrophages is not an initiating factor. The involvement of macrophages might be associated with vascular remodeling and vascular destabilization in bAVM pathogenesis [74,75].

Most of AVM studies to date have been conducted in Alk1 and Eng-deficient mice, but other members of the ENG-ALK1 signaling pathway have been tested to identify whether their deficiency contribute to AVM pathogenesis. Recent reports demonstrated that SMAD4 deficiency led to the development of bAVMs in neonatal mice [50,76]. Matrix Gla protein (MGP), an antagonist of BMPs, is involved in the regulation of VEGF expression by controlling the expression of BMP/TGF $\beta$ type I receptors [77]. Mgp gene deletion in mice caused AVMs in the brain, enhanced BMP activities, and increased expression of Notch ligands and targets [78]. A recent study showed that Sox 2 was elevated in human sporadic bAVM endothelial cells and bAVM endothelial cells of matrix Gla protein null $\left(\mathrm{Mgp}^{--}\right)$mice, causing endothelial-mesenchymal transition (EndMTs) and vessel lumen disruption [79]. Reducing Notch activity by heterozygous deletion of Jagged 1 or 2 prevented bAVM formation [78]. The expression of integrin $\beta 8$ subunit (ITGB8), interacting with TGF- $\beta$ signaling, was reduced in sporadic human bAVM [80]. Deletion of Itgb8 enhanced hemorrhage in VEGF-induced brain angiogenic foci of adult $A l k 1^{+/-}$mice, suggesting that both Itgb8 and Alk1 are important for maintaining normal cerebral angiogenesis in response to VEGF [81].

A recent report showed that CRISPR/Cas9-mediated somatic Alk1 gene mutations in wild-type mouse brain induced bAVMs with combined VEGF overexpression [82]. The advantages of this system include that it bypasses the challenges of germline modifications, such as embryonic lethality, and saves the time and cost that are needed for establishing, breeding, and maintaining genetically modified animals. It would especially be useful to generate bAVM models in animals larger than mice.

Some pathogenic variants of genes involved in BMP/TGF- $\beta$ and VEGF/VEGF receptor (VEGFR) signaling have been detected in DNA extracted from peripheral blood of sporadic bAVM patients. Some of the variants have been implicated to be pathological through testing them in zebrafish [83].

Collectively, these data suggest a specific role of BMP/TGF- $\beta$ and VEGF/VEGFR signaling in the etiology of bAVM. 


\section{Pdgfb/pdgf Receptor $\beta$ (pdgfr $\beta$ ) Pathway}

Structural imperfection and immaturity of the vascular wall suggest that bAVM vessels are maldeveloped. Abnormal vessel wall structure has also been noticed in the bAVM vessels in mouse models $[63,64]$. Compared with normal brain angiogenic foci, the lesions in bAVM mouse models have more vessels with diameters measuring larger than $15 \mu \mathrm{m}$ and lack smooth muscles.

Blood vessels are composed of endothelial cells and mural cells, including vascular smooth muscle cells and pericytes. Pericytes wrap around the endothelial cells of capillaries and venules. They have a crucial role in vascular stability. The reduction of vascular pericytes impairs vascular integrity $[84,85]$. Recent studies have shown that both human and mouse bAVM vessels have less mural cell coverage compared to normal brain vessels $[64,86,87]$, suggesting an abnormal vascular remodeling in bAVMs. Reduced vascular smooth muscle cell and pericyte coverage are associated with increased vascular permeability and bAVM hemorrhage $[64,86]$.

PDGF-B and PDGFR- $\beta$ play an essential role in pericyte- and vascular smooth muscle cell-recruitment during angiogenesis. Knocking out $P d g f b$ or $P d g f r \beta$ in mice resulted in the loss of pericytes from the microvessels [88]. The absence of pericytes also led to endothelial hyperplasia and excessive endothelial luminal membrane folds [89]. Abnormal expression of PDGF-B and PDGFR- $\beta$ has been described in bAVMs in rodent models and patients $[86,87,90]$. Pdgf $\beta$ expression was reduced in the bAVM lesions of Alk1-deficient mice [64], which is associated with a reduction of smooth muscle cell- and pericyte-coverage, suggesting a possible link between ALK1 and PDGF-B/PDGFR- $\beta$ signaling pathways. However, it is not clear whether the reduced expression of PDGFR - $\beta$ in bAVM is the cause or the result of pericyte reduction. Interestingly, overexpression of PDGF-B in Alk1-deficient bAVM increased pericyte coverage on $\mathrm{bAVM}$ vessels and reduced bAVM hemorrhage [87].

These data indicate that PDGF-B and PDGFR- $\beta$ signaling pathway play an important role in bAVM vascular integrity.

\section{Non-Coding RNA}

Recent studies showed that non-coding RNAs might also play a role in bAVM pathogenesis. $\mathrm{Li}$ et al. found four long non-coding RNAs were aberrantly expressed in AVM nidus [91]. These non-coding RNAs downregulates nicotinamide adenine dinucleotide phosphate (NADPH) reductase, lipoprotein lipase, etc., which may correlate with seizures in bAVM patients. Through deep sequencing of small RNAs in the blood of patients with bAVM, Chen et al. found novel dysregulated miRNAs, one of which targets the VEGF signaling pathways [92]. It has been observed that miRNA-137 and miRNA-196* inhibit abnormal behavior of AVM smooth muscle cells in culture [93]. In addition, a recent study demonstrated that inactivating mutations in Drosha resulted in vascular abnormalities similar to HHT in mice and angiogenesis defects in zebrafish. DROSHA variants (P100L and R279L) have been detected in HHT patients who lacked known pathogenic mutations [94]. These data indicate that microRNA processing may play a role in AVM pathogenesis.

\section{Therapeutic Applications}

The signaling pathways for sporadic bAVM and HHT, as well as potential targets for the development of new therapies, are summarized in Figure 1. 


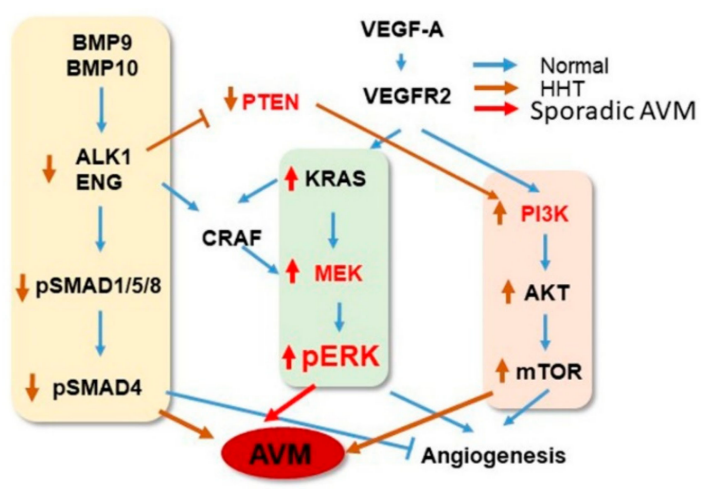

Figure 1. Signaling pathways and therapeutic targets. Normally, BMP9/TGF $\beta 1$ regulates angiogenesis through binding to ALK1/ENG to phosphorylate SMAD and increase PTEN activity, which in turn reduces PI3K signaling (blue lines and arrows). BMPs can also signal through MEK/ERK. In HHT (brown lines and arrows), mutation of ALK1 or ENG reduces PSMAD and PETN, resulting in increased PI3K activity or pERK level, causing AVM development. In sporadic AVM cases (red line and arrows), activating mutation in genes in the MAPK-ERK signaling pathway, such as KRAS, BRAF, and MAP2K1, increases the level of pERK, leading to AVM development or progression. The upregulation of PI3K may enhance AVM progression through exacerbation of angiogenesis in HHT. The genes in red can be tested as therapeutic targets.

In this review, we highlighted the most exciting finding in bAVM research in recent years, including the discovery of somatic mutations in genes in RAS-MAPK pathways in sporadic AVMs [12,13,28,29]. It has been shown that the delivery of MEK inhibitors to AVM ECs reduced ERK activity and decreased vessel abnormalities [12,29]. The existing FDA approved inhibitors for the ERK pathway (https://www.cancer.gov/about-cancer/treatment/drugs/fda-trametinib) can accelerate the translation of the knowledge obtained from this study to clinical practice.

Elevated VEGF expression in human bAVMs has been implicated in bAVM pathophysiology [95-97] and bAVM hemorrhage in a mouse bAVM model with Alk1 deletion [98]. VEGF antagonism by bevacizumab, a humanized monoclonal antibody neutralizing all VEGF-A isoforms, reduced the number of dysplastic vessels in the bAVM model in which Alk1 was deleted, and VEGF was virally overexpressed [99]. Soluble FMS-like tyrosine kinase 1 (sFLT1) contains only the extracellular domains of FLT1 (VEGFR1) and binds with VEGF strongly [100]. Intravenously delivered adeno-associated viral vector serotype-9, expressing sFLT1 (AAV9-sFLT1), reduced bAVM severity in two bAVM models; model 1 where Eng was deleted globally, and VEGF was virally overexpressed in the brain focally, and model 2 where Eng was deleted by SM22 $\alpha$-Cre [101]. Therefore, inhibition of VEGF downstream signaling could be an effective strategy to reduce bAVM severity.

Thalidomide reduces nose bleeding and stimulates vessel maturation in HHT patients and improves mural cell recruitment in the retina of $\mathrm{Eng}^{+/-}$mice [102]. Thalidomide, or its less toxic analog, lenalidomide, treatment increased pericyte coverage of bAVM vessels and reduced the number of dysplastic vessels and hemorrhage in the bAVM lesion in the adult-onset bAVM mouse model [87]. Therefore, thalidomide or lenalidomide could also be a therapeutic option to stabilize bAVM vessels and prevent $\mathrm{BAVM}$ rupture.

Currently, there is no medical therapy for bAVMs. Bevacizumab, mitogen-activated protein kinase enzyme (MEK) inhibitors, rapamycin, and thalidomide have all been used with varying degrees of efficacy for patients with non-central nervous system AVMs. The most devastating symptom of bAVM is ICH, unlike cancer-related chemotherapy that aims to shrink abnormal tumor tissue. The concept for the treatment of bAVM should be to stabilize vascular tissue and thereby decrease the risk of spontaneous ICH. Therefore, in addition to identifying the pathways that are involved in the development of AVMs, understanding the mechanisms and factors involved in vascular remodeling, 
maintenance, vascular integrity, and rupture of AVMs is crucial for developing strategies to stabilize the AVM vessel wall and prevent AVM rupture.

Funding: This research was funded by grants to Hua Su from the National Institutes of Health (R01 NS027713, R01 HL122774) and the Michael Ryan Zodda Foundation, and to S. Paul Oh from Department of Defense (PR161205) National Institutes of Health (R01 HL128525), Leducq Foundation (ATTRACT), and Barrow Neurological Foundation. Chul Han is a recipient of a postdoctoral fellowship from the Barrow Neurological Foundation.

Acknowledgments: The authors thank Shantel Weinsheimer and Candice Le Nguyen for editorial assistance and English language review.

Conflicts of Interest: The authors declare no conflict of interest.

\section{Abbreviations}

$\begin{array}{ll}\text { bAVM } & \text { Brain arteriovenous malformation } \\ \text { HHT } & \text { hereditary hemorrhagic telangiectasia } \\ \text { TGF } \beta & \text { transforming growth factor } \beta \\ \text { Pdgfb } & \text { platelet-derived growth factor b } \\ \text { ENG } & \text { endoglin } \\ \text { ALK1 or ACVLR1 } & \text { activin receptor-like kinase } 1\end{array}$

\section{References}

1. Kim, H.; Su, H.; Weinsheimer, S.; Pawlikowska, L.; Young, W.L. Brain arteriovenous malformation pathogenesis: A response-to-injury paradigm. Acta Neurochir. Suppl. 2011, 111, 83-92. [PubMed]

2. Morris, Z.; Whiteley, W.N.; Longstreth, W.T.; Weber, F.; Lee, Y.-C.; Tsushima, Y.; Alphs, H.; Ladd, S.C.; Warlow, C.; Wardlaw, J.M.; et al. Incidental findings on brain magnetic resonance imaging: Systematic review and meta-analysis. BMJ 2009, 339, b3016. [CrossRef] [PubMed]

3. Cordonnier, C.; Klijn, C.J.M.; Van Beijnum, J.; Salman, R.A.-S. Radiological Investigation of Spontaneous Intracerebral Hemorrhage: Systematic Review and Trinational Survey. Stroke 2010, 41, 685-690. [CrossRef] [PubMed]

4. Van Beijnum, J.; Lovelock, C.E.; Cordonnier, C.; Rothwell, P.M.; Klijn, C.J.; Salman, R.A. Outcome after spontaneous and arteriovenous malformation-related intracerebral haemorrhage: Population-based studies. Brain 2009, 132 Pt 2, 537-543. [CrossRef]

5. Cockroft, K.M.; Jayaraman, M.V.; Amin-Hanjani, S.; Derdeyn, C.P.; McDougall, C.G.; Wilson, J.A. A perfect storm: How a randomized trial of unruptured brain arteriovenous malformations' (ARUBA's) trial design challenges notions of external validity. Stroke 2012, 43, 1979-1981. [CrossRef]

6. Mohr, J.P.; Parides, M.K.; Stapf, C.; Moquete, E.; Moy, C.S.; Overbey, J.R.; Salman, R.A.; Vicaut, E.; Young, W.L.; Houdart, E.; et al. Medical management with or without interventional therapy for unruptured brain arteriovenous malformations (ARUBA): A multicentre, non-blinded, randomised trial. Lancet 2014, 383, 614-621. [CrossRef]

7. Al-Shahi Salman, R.; White, P.M.; Counsell, C.E.; Du Plessis, J.; Van Beijnum, J.; Josephson, C.B.; Wilkinson, T.; Wedderburn, C.J.; Chandy, Z.; St George, E.J.; et al. Outcome after conservative management or intervention for unruptured brain arteriovenous malformations. JAMA 2014, 311, 1661-1669. [CrossRef]

8. Stapf, C.; Mohr, J.P.; Choi, J.H.; Hartmann, A.; Mast, H. Invasive treatment of unruptured brain arteriovenous malformations is experimental therapy. Curr. Opin. Neurol. 2006, 19, 63-68. [CrossRef]

9. Mohr, J.P.; Moskowitz, A.J.; Stapf, C.; Hartmann, A.; Lord, K.; Marshall, S.M.; Mast, H.; Moquete, E.; Moy, C.S.; Parides, M.; et al. The ARUBA trial: Current status, future hopes. Stroke 2010, 41, e537-e540. [CrossRef]

10. Mohr, J.P.; Moskowitz, A.J.; Parides, M.; Stapf, C.; Young, W.L. Hull down on the horizon: A Randomized trial of Unruptured Brain Arteriovenous malformations (ARUBA) trial. Stroke 2012, 43, 1744-1745. [CrossRef]

11. Derdeyn, C.P.; Zipfel, G.J.; Albuquerque, F.C.; Cooke, D.L.; Feldmann, E.; Sheehan, J.P.; Torner, J.C.; On behalf of the American Heart Association Stroke Council. Management of Brain Arteriovenous Malformations: A Scientific Statement for Healthcare Professionals From the American Heart Association/American Stroke Association. Stroke 2017, 48, e200-e224. [CrossRef] [PubMed] 
12. Nikolaev, S.I.; Vetiska, S.; Bonilla, X.; Boudreau, E.; Jauhiainen, S.; Rezai Jahromi, B.; Khyzha, N.; DiStefano, P.V.; Suutarinen, S.; Kiehl, T.R.; et al. Somatic Activating KRAS Mutations in Arteriovenous Malformations of the Brain. N. Engl. J. Med. 2018, 378, 250-261. [CrossRef] [PubMed]

13. Couto, J.A.; Huang, A.Y.; Konczyk, D.J.; Goss, J.A.; Fishman, S.J.; Mulliken, J.B.; Warman, M.L.; Greene, A.K. Somatic MAP2K1 Mutations Are Associated with Extracranial Arteriovenous Malformation. Am. J. Hum. Genet. 2017, 100, 546-554. [CrossRef] [PubMed]

14. Cohen, J.C.; Kiss, R.S.; Pertsemlidis, A.; Marcel, Y.L.; McPherson, R.; Hobbs, H.H. Multiple Rare Alleles Contribute to Low Plasma Levels of HDL Cholesterol. Science 2004, 305, 869-872. [CrossRef]

15. Davit-Spraul, A.; Gonzales, E.; Baussan, C.; Jacquemin, E. Progressive familial intrahepatic cholestasis. Orphanet J. Rare Dis. 2009, 4, 1. [CrossRef]

16. Davit-Spraul, A.; Gonzales, E.; Baussan, C.; Jacquemin, E. The Spectrum of Liver Diseases Related to ABCB4 Gene Mutations: Pathophysiology and Clinical Aspects. Semin. Liver Dis. 2010, 30, 134-146. [CrossRef]

17. Davit-Spraul, A.; Fabre, M.; Branchereau, S.; Baussan, C.; Gonzales, E.; Stieger, B.; Bernard, O.; Jacquemin, E.; Davit-Spraul, A. ATP8B1 and ABCB11 analysis in 62 children with normal gamma-glutamyl transferase progressive familial intrahepatic cholestasis (PFIC): Phenotypic differences between PFIC1 and PFIC2 and natural history. Hepatology 2010, 51, 1645-1655. [CrossRef]

18. Finckh, U.; Muller-Thomsen, T.; Mann, U.; Eggers, C.; Marksteiner, J.; Meins, W.; Binetti, G.; Alberici, A.; Hock, C.; Nitsch, R.M.; et al. High prevalence of pathogenic mutations in patients with early-onset dementia detected by sequence analyses of four different genes. Am. J. Hum. Genet. 2000, 66, 110-117. [CrossRef]

19. Gonzales, E. Liver diseases related to MDR3 (ABCB4) gene deficiency. Front. Biosci. 2009, 14, 4242. [CrossRef]

20. Morita, H.; Rehm, H.L.; Menesses, A.; McDonough, B.; Roberts, A.E.; Kucherlapati, R.; Towbin, J.A.; Seidman, J.; Seidman, C.E. Shared genetic causes of cardiac hypertrophy in children and adults. N. Engl. J. Med. 2008, 358, 1899-1908. [CrossRef]

21. Ophoff, R.A.; Terwindt, G.M.; Vergouwe, M.N.; Van Eijk, R.; Oefner, P.J.; Hoffman, S.M.; Lamerdin, J.E.; Mohrenweiser, H.W.; Bulman, D.E.; Ferrari, M.; et al. Familial hemiplegic migraine and episodic ataxia type-2 are caused by mutations in the $\mathrm{Ca}^{2+}$ channel gene CACNL1A4. Cell 1996, 87, 543-552. [CrossRef]

22. Sanders, R.D.; Avidan, M.S. Postoperative cognitive trajectories in adults: The role of inflammatory processes. Anesthesiology 2013, 118, 484-486. [CrossRef] [PubMed]

23. McCubrey, J.A.; Steelman, L.S.; Chappell, W.H.; Abrams, S.L.; Wong, E.W.; Chang, F.; Lehmann, B.; Terrian, D.M.; Milella, M.; Tafuri, A.; et al. Roles of the Raf/MEK/ERK pathway in cell growth, malignant transformation and drug resistance. Biochim. Biophys. Acta 2007, 1773, 1263-1284. [CrossRef] [PubMed]

24. Malumbres, M.; Barbacid, M. RAS oncogenes: The first 30 years. Nat. Rev. Cancer 2003, 3, 459-465. [CrossRef]

25. Santarpia, L.; Myers, J.N.; Sherman, S.I.; Trimarchi, F.; Clayman, G.L.; El-Naggar, A.K. Genetic alterations in the RAS/RAF/mitogen-activated protein kinase and phosphatidylinositol 3-kinase/Akt signaling pathways in the follicular variant of papillary thyroid carcinoma. Cancer 2010, 116, 2974-2983. [CrossRef]

26. Rinehart, J.; Adjei, A.A.; Lorusso, P.M.; Waterhouse, D.; Hecht, J.R.; Natale, R.B.; Hamid, O.; Varterasian, M.; Asbury, P.; Kaldjian, E.P.; et al. Multicenter phase II study of the oral MEK inhibitor, CI-1040, in patients with advanced non-small-cell lung, breast, colon, and pancreatic cancer. J. Clin. Oncol. 2004, 22, 4456-4462. [CrossRef]

27. Sohn, S.J.; Sarvis, B.K.; Cado, D.; Winoto, A. ERK5 MAPK Regulates Embryonic Angiogenesis and Acts as a Hypoxia-sensitive Repressor of Vascular Endothelial Growth Factor Expression. J. Boil. Chem. 2002, 277, 43344-43351. [CrossRef]

28. Hong, T.; Yan, Y.; Li, J.; Radovanovic, I.; Ma, X.; Shao, Y.W.; Yu, J.; Ma, Y.; Zhang, P.; Ling, F.; et al. High prevalence of KRAS/BRAF somatic mutations in brain and spinal cord arteriovenous malformations. Brain 2019, 142, 23-34. [CrossRef]

29. Al-Olabi, L.; Polubothu, S.; Dowsett, K.; Andrews, K.A.; Stadnik, P.; Joseph, A.P.; Knox, R.; Pittman, A.; Clark, G.; Baird, W.; et al. Mosaic RAS/MAPK variants cause sporadic vascular malformations which respond to targeted therapy. J. Clin. Investig. 2018, 128, 1496-1508. [CrossRef]

30. Bayrak-Toydemir, P.; McDonald, J.; Markewitz, B.; Lewin, S.; Miller, F.; Chou, L.-S.; Gedge, F.; Tang, W.; Coon, H.; Mao, R.; et al. Genotype-phenotype correlation in hereditary hemorrhagic telangiectasia: Mutations and manifestations. Am. J. Med. Genet. Part A 2006, 140, 463-470. [CrossRef] 
31. Letteboer, T.G.; Mager, J.J.; Snijder, R.J.; Koeleman, B.P.; Lindhout, D.; Ploos van Amstel, J.K.; Westermann, C.J. Genotype-phenotype relationship in hereditary haemorrhagic telangiectasia. J. Med. Genet. 2006, 43, 371-377. [CrossRef] [PubMed]

32. Sabba, C.; Pasculli, G.; Lenato, G.M.; Suppressa, P.; Lastella, P.; Memeo, M.; Dicuonzo, F.; Guanti, G. Hereditary hemorragic telangiectasia: Clinical features in ENG and ALK1 mutation carriers. J. Thromb. Haemost. 2007, 5, 1149-1157. [CrossRef] [PubMed]

33. Govani, F.S.; Shovlin, C.L. Hereditary haemorrhagic telangiectasia: A clinical and scientific review. Eur. J. Hum. Genet. 2009, 17, 860-871. [CrossRef] [PubMed]

34. McAllister, K.A.; Grogg, K.M.; Johnson, D.W.; Gallione, C.J.; Baldwin, M.A.; Jackson, C.E.; Helmbold, E.A.; Markel, D.S.; McKinnon, W.C.; Murrell, J.; et al. Endoglin, a TGF-beta binding protein of endothelial cells, is the gene for hereditary haemorrhagic telangiectasia type 1. Nat. Genet. 1994, 8, 345-351. [CrossRef]

35. Johnson, D.; Berg, J.; Baldwin, M.; Gallione, C.; Marondel, I.; Yoon, S.-J.; Stenzel, T.; Speer, M.; Pericak-Vance, M.; Diamond, A.; et al. Mutations in the activin receptor-like kinase 1 gene in hereditary haemorrhagic telangiectasia type 2. Nat. Genet. 1996, 13, 189-195. [CrossRef]

36. Gallione, C.J.; Repetto, G.M.; Legius, E.; Rustgi, A.K.; Schelley, S.L.; Tejpar, S.; Mitchell, G.; Drouin, E.; Westermann, C.J.; Marchuk, D.A. A combined syndrome of juvenile polyposis and hereditary haemorrhagic telangiectasia associated with mutations in MADH4 (SMAD4). Lancet 2004, 363, 852-859. [CrossRef]

37. McDonald, J.; Wooderchak-Donahue, W.; Webb, C.V.; Whitehead, K.; Stevenson, D.A.; Bayrak-Toydemir, P. Hereditary hemorrhagic telangiectasia: Genetics and molecular diagnostics in a new era. Front. Genet. 2015, 6, 1. [CrossRef]

38. Tual-Chalot, S.; Oh, S.P.; Arthur, H.M. Mouse models of hereditary hemorrhagic telangiectasia: Recent advances and future challenges. Front. Genet. 2015, 6, 25. [CrossRef]

39. Lesca, G.; Olivieri, C.; Burnichon, N.; Pagella, F.; Carette, M.-F.; Gilbert-Dussardier, B.; Goizet, C.; Roume, J.; Rabilloud, M.; Saurin, J.-C.; et al. Genotype-phenotype correlations in hereditary hemorrhagic telangiectasia: Data from the French-Italian HHT network. Genet. Med. 2007, 9, 14-22. [CrossRef]

40. Shovlin, C.L. Hereditary haemorrhagic telangiectasia: Pathophysiology, diagnosis and treatment. Blood Rev. 2010, 24, 203-219. [CrossRef]

41. Komiyama, M.; Ishiguro, T.; Yamada, O.; Morisaki, H.; Morisaki, T. Hereditary hemorrhagic telangiectasia in Japanese patients. J. Hum. Genet. 2014, 59, 37-41. [CrossRef] [PubMed]

42. Brinjikji, W.; Iyer, V.N.; Wood, C.P.; Lanzino, G. Prevalence and characteristics of brain arteriovenous malformations in hereditary hemorrhagic telangiectasia: A systematic review and meta-analysis. J. Neurosurg. 2017, 127, 302-310. [CrossRef] [PubMed]

43. Pardali, E.; Ten Dijke, P. TGFbeta signaling and cardiovascular diseases. Int. J. Biol. Sci. 2012, 8, $195-213$. [CrossRef]

44. Chen, H.; Ridgway, J.B.; Sai, T.; Lai, J.; Warming, S.; Chen, H.; Roose-Girma, M.; Zhang, G.; Shou, W.; Yan, M. Context-dependent signaling defines roles of BMP9 and BMP10 in embryonic and postnatal development. Proc. Natl. Acad. Sci. USA 2013, 110, 11887-11892. [CrossRef] [PubMed]

45. Ricard, N.; Ciais, D.; Levet, S.; Subileau, M.; Mallet, C.; Zimmers, T.A.; Lee, S.-J.; Bidart, M.; Feige, J.-J.; Bailly, S. BMP9 and BMP10 are critical for postnatal retinal vascular remodeling. Blood 2012, 119, 6162-6171. [CrossRef] [PubMed]

46. Laux, D.W.; Young, S.; Donovan, J.P.; Mansfield, C.J.; Upton, P.D.; Roman, B.L. Circulating Bmp10 acts through endothelial Alk1 to mediate flow-dependent arterial quiescence. Development 2013, 140, 3403-3412. [CrossRef] [PubMed]

47. Roman, B.L.; Hinck, A.P. ALK1 signaling in development and disease: New paradigms. Cell. Mol. Life Sci. 2017, 74, 4539-4560. [CrossRef]

48. Zhang, Y.E. Non-Smad pathways in TGF-beta signaling. Cell Res. 2009, 19, 128-139. [CrossRef]

49. Alsina-Sanchis, E.; García-Ibáñez, Y.; Figueiredo, A.M.; Riera-Domingo, C.; Figueras, A.; Matias-Guiu, X.; Casanovas, O.; Botella, L.M.; Pujana, M.A.; Riera-Mestre, A.; et al. ALK1 Loss Results in Vascular Hyperplasia in Mice and Humans Through PI3K Activation. Arterioscler. Thromb. Vasc. Boil. 2018, 38, 1216-1229. [CrossRef]

50. Ola, R.; Dubrac, A.; Han, J.; Zhang, F.; Fang, J.S.; Larrivée, B.; Lee, M.; Urarte, A.A.; Kraehling, J.R.; Genet, G.; et al. PI3 kinase inhibition improves vascular malformations in mouse models of hereditary haemorrhagic telangiectasia. Nat. Commun. 2016, 7, 13650. [CrossRef] 
51. Bischoff, J. PTEN (Phosphatase and Tensin Homolog) Connection in Hereditary Hemorrhagic Telangiectasia 2. Arterioscler. Thromb. Vasc. Biol. 2018, 38, 984-985. [CrossRef] [PubMed]

52. Vazquez, F.; Ramaswamy, S.; Nakamura, N.; Sellers, W.R. Phosphorylation of the PTEN Tail Regulates Protein Stability and Function. Mol. Cell. Boil. 2000, 20, 5010-5018. [CrossRef]

53. Vazquez, F.; Grossman, S.R.; Takahashi, Y.; Rokas, M.V.; Nakamura, N.; Sellers, W.R. Phosphorylation of the PTEN Tail Acts as an Inhibitory Switch by Preventing Its Recruitment into a Protein Complex. J. Boil. Chem. 2001, 276, 48627-48630. [CrossRef] [PubMed]

54. Bourdeau, A.; Dumont, D.J.; Letarte, M. A murine model of hereditary hemorrhagic telangiectasia. J. Clin. Investig. 1999, 104, 1343-1351. [CrossRef] [PubMed]

55. Torsney, E.; Charlton, R.; Diamond, A.G.; Burn, J.; Soames, J.V.; Arthur, H.M. Mouse Model for Hereditary Hemorrhagic Telangiectasia Has a Generalized Vascular Abnormality. Circulation 2003, 107, 1653-1657. [CrossRef] [PubMed]

56. Satomi, J.; Mount, R.J.; Toporsian, M.; Paterson, A.D.; Wallace, M.C.; Harrison, R.V.; Letarte, M.; Mount, R.J. Cerebral Vascular Abnormalities in a Murine Model of Hereditary Hemorrhagic Telangiectasia. Stroke 2003, 34, 783-789. [CrossRef] [PubMed]

57. Srinivasan, S.; Hanes, M.A.; Dickens, T.; Porteous, M.E.M.; Oh, S.P.; Hale, L.P.; Marchuk, D.A. A mouse model for hereditary hemorrhagic telangiectasia (HHT) type 2. Hum. Mol. Genet. 2003, 12, 473-482. [CrossRef]

58. Oh, S.P.; Seki, T.; Goss, K.A.; Imamura, T.; Yi, Y.; Donahoe, P.K.; Li, L.; Miyazono, K.; Dijke, P.T.; Kim, S.; et al. Activin receptor-like kinase 1 modulates transforming growth factor-beta 1 signaling in the regulation of angiogenesis. Proc. Natl. Acad. Sci. USA 2000, 97, 2626-2631. [CrossRef]

59. Arthur, H.M.; Ure, J.; Smith, A.J.; Renforth, G.; Wilson, D.I.; Torsney, E.; Charlton, R.; Parums, D.V.; Jowett, T.; Marchuk, D.A.; et al. Endoglin, an ancillary TGFbeta receptor, is required for extraembryonic angiogenesis and plays a key role in heart development. Dev. Biol. 2000, 217, 42-53. [CrossRef]

60. Choi, E.-J.; Chen, W.; Jun, K.; Arthur, H.M.; Young, W.L.; Su, H. Novel Brain Arteriovenous Malformation Mouse Models for Type 1 Hereditary Hemorrhagic Telangiectasia. PLoS ONE 2014, 9, e88511. [CrossRef]

61. Milton, I.; Ouyang, D.; Allen, C.J.; Yanasak, N.E.; Gossage, J.R.; Alleyne, C.H.; Seki, T. Age-Dependent Lethality in Novel Transgenic Mouse Models of Central Nervous System Arteriovenous Malformations. Stroke 2012, 43, 1432-1435. [CrossRef] [PubMed]

62. Park, S.O.; Wankhede, M.; Lee, Y.J.; Choi, E.-J.; Fliess, N.; Choe, S.-W.; Oh, S.-H.; Walter, G.; Raizada, M.K.; Sorg, B.S.; et al. Real-time imaging of de novo arteriovenous malformation in a mouse model of hereditary hemorrhagic telangiectasia. J. Clin. Investig. 2009, 119, 3487-3496. [CrossRef] [PubMed]

63. Walker, E.J.; Su, H.; Shen, F.; Choi, E.-J.; Oh, S.P.; Chen, G.; Lawton, M.T.; Kim, H.; Chen, Y.; Chen, W.; et al. Arteriovenous malformation in the adult mouse brain resembling the human disease. Ann. Neurol. 2011, 69, 954-962. [CrossRef] [PubMed]

64. Chen, W.; Guo, Y.; Walker, E.J.; Shen, F.; Jun, K.; Oh, S.P.; Degos, V.; Lawton, M.T.; Tihan, T.; Davalos, D.; et al. Reduced mural cell coverage and impaired vessel integrity after angiogenic stimulation in the Alk1-deficient brain. Arterioscler. Thromb. Vasc. Biol. 2013, 33, 305-310. [CrossRef] [PubMed]

65. Chen, W.; Sun, Z.; Han, Z.; Jun, K.; Camus, M.; Wankhede, M.; Mao, L.; Arnold, T.; Young, W.L.; Su, H. De novo cerebrovascular malformation in the adult mouse after endothelial Alk1 deletion and angiogenic stimulation. Stroke 2014, 45, 900-902. [CrossRef]

66. Choi, E.-J.; Walker, E.J.; Shen, F.; Oh, S.P.; Arthur, H.M.; Young, W.L.; Su, H. Minimal Homozygous Endothelial Deletion of Eng with VEGF Stimulation is Sufficient to Cause Cerebrovascular Dysplasia in the Adult Mouse. Cerebrovasc. Dis. 2012, 33, 540-547. [CrossRef]

67. Garrido-Martin, E.M.; Nguyen, H.-L.; Cunningham, T.A.; Choe, S.-W.; Jiang, Z.; Arthur, H.M.; Lee, Y.-J.; Oh, S.P. Common and Distinctive Pathogenetic Features of Arteriovenous Malformations in Hereditary Hemorrhagic Telangiectasia 1 and Hereditary Hemorrhagic Telangiectasia 2 Animal Models-Brief Report. Arterioscler. Thromb. Vasc. Boil. 2014, 34, 2232-2236. [CrossRef]

68. Choi, E.-J.; Walker, E.J.; Degos, V.; Jun, K.; Kuo, R.; Pile-Spellman, J.; Su, H.; Young, W.L. Endoglin deficiency in bone marrow is sufficient to cause cerebrovascular dysplasia in the adult mouse after vascular endothelial growth factor stimulation. Stroke 2013, 44, 795-798. [CrossRef]

69. Chen, Y. MMP-9 expression is associated with leukocytic but not endothelial markers in brain arteriovenous malformations. Front. Biosci. 2006, 11, 3121. [CrossRef] 
70. Chen, Y.; Pawlikowska, L.; Yao, J.S.; Shen, F.; Zhai, W.; Achrol, A.S.; Lawton, M.T.; Kwok, P.Y.; Yang, G.Y.; Young, W.L. Interleukin-6 involvement in brain arteriovenous malformations. Ann. Neurol. 2006, 59, 72-80. [CrossRef]

71. Chen, Y.; Zhu, W.; Bollen, A.W.; Lawton, M.T.; Barbaro, N.M.; Dowd, C.F.; Hashimoto, T.; Yang, G.-Y.; Young, W.L. Evidence of inflammatory cell involvement in brain arteriovenous malformations. Neurosurgery 2008, 62, 1340-1350. [CrossRef] [PubMed]

72. Ma, L.; Guo, Y.; Zhao, Y.-L.; Su, H. The Role of Macrophage in the Pathogenesis of Brain Arteriovenous Malformation. Int. J. Hematol. Res. 2015, 1, 52-56. [CrossRef] [PubMed]

73. Zhang, R.; Han, Z.; Degos, V.; Shen, F.; Choi, E.-J.; Sun, Z.; Kang, S.; Wong, M.; Zhu, W.; Zhan, L.; et al. Persistent infiltration and pro-inflammatory differentiation of monocytes cause unresolved inflammation in brain arteriovenous malformation. Angiogenesis 2016, 19, 451-461. [CrossRef] [PubMed]

74. Chen, G.; Zheng, M.; Shu, H.; Zhan, S.; Wang, H.; Zhou, D.; Zeng, S.; Tang, K.; Feng, L. Macrophage migration inhibitory factor reduces apoptosis in cerebral arteriovenous malformations. Neurosci. Lett. 2012, 508, 84-88. [CrossRef]

75. Chen, W.; Choi, E.-J.; McDougall, C.M.; Su, H. Brain arteriovenous malformation modeling, pathogenesis, and novel therapeutic targets. Transl. Stroke Res. 2014, 5, 316-329. [CrossRef]

76. Kim, Y.H.; Choe, S.; Chae, M.; Hong, S.; Oh, S.P. SMAD4 Deficiency Leads to Development of Arteriovenous Malformations in Neonatal and Adult Mice. J. Am. Hear. Assoc. 2018, 7, e009514. [CrossRef]

77. Yao, Y.; Jumabay, M.; Wang, A.; Boström, K.I. Matrix Gla protein deficiency causes arteriovenous malformations in mice. J. Clin. Investig. 2011, 121, 2993-3004. [CrossRef]

78. Yao, Y.; Yao, J.; Radparvar, M.; Blazquez-Medela, A.M.; Guihard, P.J.; Jumabay, M.; Boström, K.I. Reducing Jagged 1 and 2 levels prevents cerebral arteriovenous malformations in matrix Gla protein deficiency. Proc. Natl. Acad. Sci. USA 2013, 110, 19071-19076. [CrossRef]

79. Yao, J.; Wu, X.; Zhang, D.; Wang, L.; Zhang, L.; Reynolds, E.X.; Hernandez, C.; Boström, K.I.; Yao, Y. Elevated endothelial Sox2 causes lumen disruption and cerebral arteriovenous malformations. J. Clin. Investig. 2019, 129, 3121-3133. [CrossRef]

80. Su, H.; Kim, H.; Pawlikowska, L.; Kitamura, H.; Shen, F.; Cambier, S.; Markovics, J.; Lawton, M.T.; Sidney, S.; Bollen, A.W.; et al. Reduced expression of integrin alphavbeta8 is associated with brain arteriovenous malformation pathogenesis. Am. J. Pathol. 2010, 176, 1018-1027. [CrossRef]

81. Ma, L.; Shen, F.; Jun, K.; Bao, C.; Kuo, R.; Young, W.L.; Nishimura, S.L.; Su, H. Integrin beta8 Deletion Enhances Vascular Dysplasia and Hemorrhage in the Brain of Adult Alk1 Heterozygous Mice. Transl. Stroke Res. 2016, 7, 488-496. [CrossRef] [PubMed]

82. Zhu, W.; Saw, D.; Weiss, M.; Sun, Z.; Wei, M.; Shaligram, S.; Wang, S.; Su, H. Induction of Brain Arteriovenous Malformation Through CRISPR/Cas9-Mediated Somatic Alk1 Gene Mutations in Adult Mice. Transl. Stroke Res. 2018, 10, 557-565. [CrossRef] [PubMed]

83. Wang, K.; Zhao, S.; Liu, B.; Zhang, Q.; Li, Y.; Liu, J.; Shen, Y.; Ding, X.; Lin, J.; Wu, Y.; et al. Perturbations of BMP/TGF-beta and VEGF/VEGFR signalling pathways in non-syndromic sporadic brain arteriovenous malformations (BAVM). J. Med. Genet. 2018, 55, 675-684. [CrossRef]

84. Bell, R.D.; Winkler, E.A.; Sagare, A.P.; Singh, I.; LaRue, B.; Deane, R.; Zlokovic, B.V. Pericytes control key neurovascular functions and neuronal phenotype in the adult brain and during brain aging. Neuron 2010, 68, 409-427. [CrossRef] [PubMed]

85. Armulik, A.; Genové, G.; Mäe, M.; Nisancioglu, M.H.; Wallgard, E.; Niaudet, C.; He, L.; Norlin, J.; Lindblom, P.; Strittmatter, K.; et al. Pericytes regulate the blood-brain barrier. Nature 2010, 468, 557-561. [CrossRef] [PubMed]

86. Winkler, E.A.; Birk, H.; Burkhardt, J.-K.; Chen, X.; Yue, J.K.; Guo, D.; Rutledge, W.C.; Lasker, G.F.; Partow, C.; Tihan, T.; et al. Reductions in brain pericytes are associated with arteriovenous malformation vascular instability. J. Neurosurg. 2018, 129, 1464-1474. [CrossRef] [PubMed]

87. Zhu, W.; Chen, W.; Zou, D.; Wang, L.; Bao, C.; Zhan, L.; Saw, D.; Wang, S.; Winkler, E.; Li, Z.; et al. Thalidomide Reduces Hemorrhage of Brain Arteriovenous Malformations in a Mouse Model. Stroke 2018, 49, 1232-1240. [CrossRef]

88. Lindahl, P. Pericyte Loss and Microaneurysm Formation in PDGF-B-Deficient Mice. Science 1997, 277, 242-245. [CrossRef] 
89. Hellström, M.; Gerhardt, H.; Kalén, M.; Li, X.; Eriksson, U.; Wolburg, H.; Betsholtz, C. Lack of Pericytes Leads to Endothelial Hyperplasia and Abnormal Vascular Morphogenesis. J. Cell Boil. 2001, 153, 543-554. [CrossRef]

90. Yildirim, O.; Biçer, A.; Özkan, A.; Kurtkaya, Ö.; Cirakoglu, B.; Kiliç, T. Expression of platelet-derived growth factor ligand and receptor in cerebral arteriovenous and cavernous malformations. J. Clin. Neurosci. 2010, 17, 1557-1562. [CrossRef]

91. Li, X.; Lin, F.; Wu, J.; Wang, S. LncRNAs expression signatures of human brain arteriovenous malformation revealed by microarray. Medicine 2018, 97, e11308. [CrossRef] [PubMed]

92. Chen, Y.; Li, Z.; Shi, Y.; Huang, G.; Chen, L.; Tan, H.; Wang, Z.; Yin, C.; Hu, J. Deep Sequencing of Small RNAs in Blood of Patients with Brain Arteriovenous Malformations. World Neurosurg. 2018, 115, e570-e579. [CrossRef] [PubMed]

93. Huang, J.; Song, J.; Qu, M.; Wang, Y.; An, Q.; Song, Y.; Yan, W.; Wang, B.; Wang, X.; Zhang, S.; et al. MicroRNA-137 and microRNA-195* inhibit vasculogenesis in brain arteriovenous malformations. Ann. Neurol. 2017, 82, 371-384. [CrossRef] [PubMed]

94. Jiang, X.; Wooderchak-Donahue, W.L.; McDonald, J.; Ghatpande, P.; Baalbaki, M.; Sandoval, M.; Hart, D.; Clay, H.; Coughlin, S.; Lagna, G.; et al. Inactivating mutations in Drosha mediate vascular abnormalities similar to hereditary hemorrhagic telangiectasia. Sci. Signal. 2018, 11, eaan6831. [CrossRef] [PubMed]

95. Hashimoto, T.; Lawton, M.T.; Wen, G.; Yang, G.-Y.; Chaly, T.; Stewart, C.L.; Dressman, H.K.; Barbaro, N.M.; Marchuk, D.A.; Young, W.L. Gene microarray analysis of human brain arteriovenous malformations. Neurosurgery 2004, 54, 410-425. [CrossRef] [PubMed]

96. Rothbart, D.; Awad, I.A.; Lee, J.; Kim, J.; Harbaugh, R.; Criscuolo, G.R. Expression of angiogenic factors and stuctural proteins in central nervous system vascular malformations. Neurosurgery 1996, 38, 915-924, discussion 924-925. [CrossRef] [PubMed]

97. Jabbour, M.N.; Elder, J.B.; Samuelson, C.G.; Khashabi, S.; Hofman, F.M.; Giannotta, S.L.; Liu, C.Y. Aberrant angiogenic characteristics of human brain arteriovenous malformation endothelial cells. Neurosurgery 2009, 64, 139-148. [CrossRef]

98. Cheng, P.; Ma, L.; Shaligram, S.; Walker, E.J.; Yang, S.-T.; Tang, C.; Zhu, W.; Zhan, L.; Li, Q.; Zhu, X.; et al. Effect of elevation of vascular endothelial growth factor level on exacerbation of hemorrhage in mouse brain arteriovenous malformation. J. Neurosurg. 2019, 1-8. [CrossRef]

99. Walker, E.J.; Su, H.; Shen, F.; Degos, V.; Amend, G.; Jun, K.; Young, W.L. Bevacizumab attenuates VEGF-induced angiogenesis and vascular malformations in the adult mouse brain. Stroke 2012, 43, 1925-1930. [CrossRef]

100. Chung, A.S.; Ferrara, N. Developmental and Pathological Angiogenesis. Annu. Rev. Cell Dev. Boil. 2011, 27, 563-584. [CrossRef]

101. Zhu, W.; Shen, F.; Mao, L.; Zhan, L.; Kang, S.; Sun, Z.; Nelson, J.; Zhang, R.; Zou, D.; McDougall, C.M.; et al. Soluble FLT1 Gene Therapy Alleviates Brain Arteriovenous Malformation Severity. Stroke 2017, 48, 1420-1423. [CrossRef] [PubMed]

102. Lebrin, F.; Srun, S.; Raymond, K.; Martin, S.; Brink, S.V.D.; Freitas, C.; Bréant, C.; Mathivet, T.; Larrivée, B.; Thomas, J.-L.; et al. Thalidomide stimulates vessel maturation and reduces epistaxis in individuals with hereditary hemorrhagic telangiectasia. Nat. Med. 2010, 16, 420-428. [CrossRef] [PubMed] 